\title{
KOVÁCS ISTVÁN
}

\section{Jogharmonizáció vagy sem?}

Harmadik rész:
a New York-i egyezmény és a 13/2014. (V. 16.) ORFK utasítás

A tanulmány első részében ${ }^{1}$ igazolást nyert, hogy Magyarország a szexuális célú emberkereskedelem, a prostitúcióból hasznot húzó, kizsákmányoló, és élösdi cselekmények ellen szigorúan a jogszabályi keretek között, a nemzetközi joggal összhangban fel kíván lépni. A hatályos magyar büntetőtörvény a nemzetközi egyezmények elöirásait (az előkészület stádiuma büntetendőségének kivételével) abszolválta. Ez a különbözőség - amely a büncselekmények elökészületi részében mutatkozik - azonban a törvény generális céljától nem tér el, a szexuális kizsákmányolást elkövető személyek a törvény egyik legszigorúbb büntetésére számíthatnak. A jogalkotási hierarchia legfelsőbb szintje, a büntető igazságszolgáltatás (a prostitúció jelenségének tárgyában) a nemzetközi egyezménnyel a vizsgált cikkelyek tekintetében harmonizál. A kizsákmányoló és élősdi jellegủ bủncselekmények elkövetői a magyar büntetőjog-alkotás szankcióival büntethetők és büntetendők.

A tanulmány második részében² felvetödött a kérdés, hogy ha a büntetöjog az ultima ratio elvén e társadalmi viszonyokba beavatkozni kényszerül, akkor a szabálysértési törvény rendelkezései milyen céllal születtek meg. A második részben több olyan norma is a vizsgálat tárgyául szolgált, ami a szabálysértési törvény keretének tartalmát kitöltötte. Az egyezményben (ezáltal a törvényerejü rendeletben is) négy olyan cikkely található, amely a prostituáltak munkavégzésére, a reszocializációs intézkedésekre, az áldozatvédelemre és az alapvető emberi jogok megtartására vonatkozik. A magyar szabálysértésijogalkotás a nemzetközi kötelezettségvállalással és a joggyakorlással összefüggésben olyan rendelkezést alkotott meg, amely az egyezmény preambulumában megfogalmazott célokat, és különösen a prostituáltakra vonatkozó cikkelyeket sérti, és veszélyezteti. Az elöitélet-alapú gondolkodásmód, így a prostituáltak büntethetőségének megteremtése, amely önmagában is ellentétes

1 Kovács István: Jogharmonizáció vagy sem? Első rész: a New Yorki Egyezmény és a 2012. évi C. törvény - a Büntetö Törvénykönyv. Jogelméleti Szemle, 2017/2., 89-106. o.

2 Kovács István: Jogharmonizáció vagy sem? Második rész: a New Yorki Egyezmény, valamint a 2012. évi II. és a 1999. évi LXXV. törvény. Acta Humana, 2017/5. (Megjelenés alatt.) 
a nemzetközi joggal, valamint erre a mintára épülő jogalkalmazás jogsérelemhez, és visszásságokhoz vezet(het).

E tanulmány feladata a prostitúcióval összefüggő jogsértések és az emberkereskedelem kezelésével kapcsolatos rendőri feladatok végrehajtásáról szóló13/2014. (V. 16.) számú ORFK utasítás vizsgálata. Bár már a cím is a rendőrség prostituáltakkal kapcsolatos pejoratív intézkedésére utal, a tudományos munka sosem anticipálhat, ezért olyan kézzelfogható eredmény felmutatására van szükség, amely az előbbieknek ellentmond, vagy azokat megerösíti. E tanulmány stratégiai célként határozta meg, hogy az egyezménnyel összhangban a címben szereplö utasítást megvizsgálja, különös tekintettel arra, hogy az utasítás kiadója milyen intézkedések bevezetését tartotta indokoltnak a nemzetközi kötelezettségvállalással és a joggyakorlással összefüggésben. Hipotézisem szerint a rendőrség utasítása a New York-i egyezmény szellemével összeegyeztethetetlen, annak rendelkezései a nemzetközi norma preambulumában megfogalmazott célokat sértik, az leginkább a szabálysértési törvényben megfogalmazottakhoz igazodik.

Mindezek ellenőrzésére olyan elméleti kutatási módszert kellett választanom, amely a köznapi gondolkodás szerves alkotóeleme, szakaszai absztrahálhatók, és logika alkalmazását követelik meg. Választásom így az összehasonlítás kutatási módszertanára esett, amely a vizsgálat tárgyáról számos ítéletet feltételez, ezek egymással szoros összefüggésben állnak, az ismereteket pedig a keletkezett rendszeren belül az azonosság, a hasonlóság, a különbség, és az össze nem vethetőség szempontja választja szét. Reményeim szerint a választott kutatási módszertan megerősíti és/vagy cáfolja a hipotézisemben foglaltakat, elősegítve ezzel új tudományos eredmények létrejöttét.

\section{A rendőrség saját hatásköre}

Irányított ügyeire vonatkozóan az Országos Rendőr-főkapitányságot (és alárendelt szerveit) szabályozási jog gyakorlása, a normatív döntéshozatal lehetősége illeti meg. (A szabályozási jog elsődlegesen jogszabályi formában, de az állami irányítás egyéb jogi eszközeiben is megjelenhet. A rendőrség által kibocsátható normatív határozatok és az utasítások is e kategória szerves részei.) ${ }^{3}$ Országos hatáskörü szervként a saját hatáskörben gyakorolható ak-

3 Torma András - Kalas Tibor - Nyitrai Péter - Czékmann Zsolt - Bodnár Norbert: Közigazgatási jog

1. Magyar Közigazgatási jog általános rész. Miskolci Egyetem Állam- és Jogtudományi Kar, Miskolc,

2012. Pap Gábor: Az új jogalkotási törvényröl. Sectio Juridica et Politica, Tomus, 2011/1., 268. o.

Belügyi Szemle, 2017/10. 
tusai közül a konkrét utasítás a legerösebb irányítási jogosítvány, amely - az irányított szerv vonatkozásában - kötelezettséget keletkeztet, módosít vagy szüntet meg. Az elöbbiekkel összefüggésben a rendőrségnek olyan aktus megalkotására volt szüksége, amely megteremti a prostitúcióval kapcsolatos rendőri feladatok végrehajtásának lehetőségét.

Tekintettel arra, hogy a tanulmány a hatályos utasítás vizsgálatával foglalkozik, és a szervezett bünözés elleni törvény is csak 1999-ben jelent meg, irreleváns az az elötti történeti időszakot vizsgálni. ${ }^{4}$ Jelenleg a prostitúcióval összefüggő jogsértések és az emberkereskedelem kezelésével kapcsolatos rendőri feladatok végrehajtásáról a 14/2016. (V. 27.) ORFK utasítással módosított 13/2014. (V. 16.) ORFK utasítás rendelkezik. ${ }^{5}$ Az utasítás kiadására az országos rendőrfökapitány 2014-ben a jogalkotásról szóló 2010. évi CXXX. törvény 23 . § (4) bekezdés c) pontjában, valamint a rendőrségről szóló 1994. évi XXXIV. törvény 6 . § (1) bekezdés b) pontjában kapott felhatalmazás alapján intézkedett. ${ }^{6}$

Míg szervi hatálya az általános rendőrségi feladatok ellátására létrehozott szervre - összefoglalóan a rendőrségre -, addig tárgyi hatálya

- egyrészt a büntető törvénykönyvről szóló 2012. évi C. törvény 192. §-ába ütköző emberkereskedelem büncselekményére, továbbá a prostitúcióra kényszerítéshez, szexuális kizsákmányoláshoz kapcsolódó cselekmények mellett az emberkereskedelem más formáihoz, így különösen a kényszermunkához, szervkereskedelemhez, bérkolduláshoz, tiltott örökbefogadáshoz

4 A szervezett bünözés, valamint az azzal összefüggö egyes jelenségek elleni fellépés szabályairól és az ehhez kapcsolódó törvénymódosításokról szóló 1999. évi LXXV. törvény. Hatályba lépett: 1999. július 5. https://net.jogtar.hu/jr/gen/hjegy_doc.cgi?docid=99900075.TV

5 A prostitúcióval összefüggö jogsértések és az emberkereskedelem kezelésével kapcsolatos rendőri feladatok végrehajtásáról szóló 13/2014. (V. 16.) ORFK utasítás. Hatályba lépett: 2014. május 16. https://net.jogtar.hu/jr/gen/hjegy_doc.cgi?docid=99900075.TV; 14/2016. (V. 27.) ORFK utasitás egyes ORFK utasítások módosításáról. Hatályba lépett: 2016. május 27. https://net.jogtar.hu/jr /gen/hjegy_doc.cgi?docid=99900075.TV. Érdekesség, hogy a szervezett bünözés elleni jogsértések kezeléséről szóló törvénnyel összhangban elöször az 59/1999. (XII. 8.) ORFK intézkedés kiadására kerül sor, amely csak a prostituáltakkal összefüggő rendészeti feladatok végrehajtásáról rendelkezett. Ennek módosítására adták ki az 5/2001. (III. 1.) ORFK intézkedést, amely beemelte az emberkereskedelemmel kapcsolatos rendőri feladatok végrehajtását is. Kronológiailag a hatályos szabályozás elött a 4/2006. (I. 23.) ORFK intézkedés, majd a 46/2007. (OT. 30.) ORFK utasítás volt érvényben.

6 A jogalkotásról szóló 2010. évi CXXX. törvény. Hatályba lépett: 2010. november 29. https://net.jogtar.hu/jr/gen/hjegy_doc.cgi?docid=99900075.TV; a rendörségröl szóló 1994. évi XXXIV. törvény. Hatályba lépett: 1994. április 20. https://net.jogtar.hu/jr/gen/hjegy_doc.cgi?docid=99900075.TV

7 A büntető törvénykönyvröl szóló 2012. évi C. törvény. Hatályba lépett: 2012. július 13 . https://net.jogtar.hu/jr/gen/hjegy_doc.cgi?docid=A1200100.TV 
- másrészt a szabálysértésekről, a szabálysértési eljárásról és a szabálysértési nyilvántartási rendszerről szóló 2012. évi II. törvényben szabályozott prostitúcióhoz kapcsolódó jogsértésekre terjed ki. ${ }^{8}$

A következőkben szükséges tehát annak vizsgálata, hogy a rendőrségi utasítás valóban a nemzetközi egyezményhez asszimilálódott-e, vagy követve a magyar büntetőjogi és szabálysértési szabályozást, annak megfelelve készült. Bár a tárgyi hatály erre enged következtetni, mégis úgy gondolom, hogy szükséges elvégezni az egyezményi rendelkezések harmonizációjának vizsgálatát.

\section{A New York-i egyezmény deharmonizációja és/vagy harmonizációja}

Az egyezmény célját és jogpolitikai indokát már ismertettem. A csoportosítás alapját e tanulmányban - függetlenül annak szabálysértési és/vagy büntetöszabályozási voltától - az egyezmény cikkelyeiben kitüzött feladatok, és a részes államra háruló kötelezettségvállalás adta. Példának okáért, a prostituáltak áldozati jellegének elfogadása, és a társadalomba való reintegrálásának segítése nemcsak a büntető-, hanem a szabálysértési eljárás tárgyát is alkotja. A fenti logikát követve így két fö- és három alcsoportot különböztettem meg. A főcsoportot a rendvédelmi feladatokat ellátó szerv általános és az egyéb - nem a rendvédelmi szerv - intézkedési kötelmei alkották. Az alcsoportok a következők szerint az első főcsoport alá tagozódtak: a prostitútorokkal; a prostituáltakkal; és az együttmüködéssel kapcsolatos intézkedések.

$\mathrm{Az}$ első föcsoportba minden olyan intézkedés beletartozott, amelyet a rendvédelmi szervek a tárgykörrel kapcsolatban végrehajtani kötelesek. Az első alcsoport a prostitútorokkal kapcsolatos intézkedéseket tartalmazta, amely egyebek között az üldöztetéssel és a szankcionálással kapcsolatos rendőri feladatokat integrálta. A második alcsoport a prostituáltakkal kapcsolatos rendőri intézkedéseket ölelte fel, különös tekintettel a reszocializációt, a társadalmi reintegrációt elősegítő rendelkezésekre, és az áldozatvédelmi intézkedésekre. A harmadik csoport az együttműködéssel kapcsolatos intézkedéseket gyüjtötte össze, vagyis a nemzetközi információcserén és tájékozta-

8 A szabálysértésekröl, a szabálysértési eljárásról és a szabálysértési nyilvántartásról szóló 2012. évi II. törvény. Hatályba lépett: 2012. április 15.

https://net.jogtar.hu/jr/gen/hjegy_doc.cgi?docid=A1200002.TV

Belügyi Szemle, 2017/10. 
1. számú ábra

A New York-i egyezmény és annak törvényerejű rendelete cikkelyeinek csoportosítása

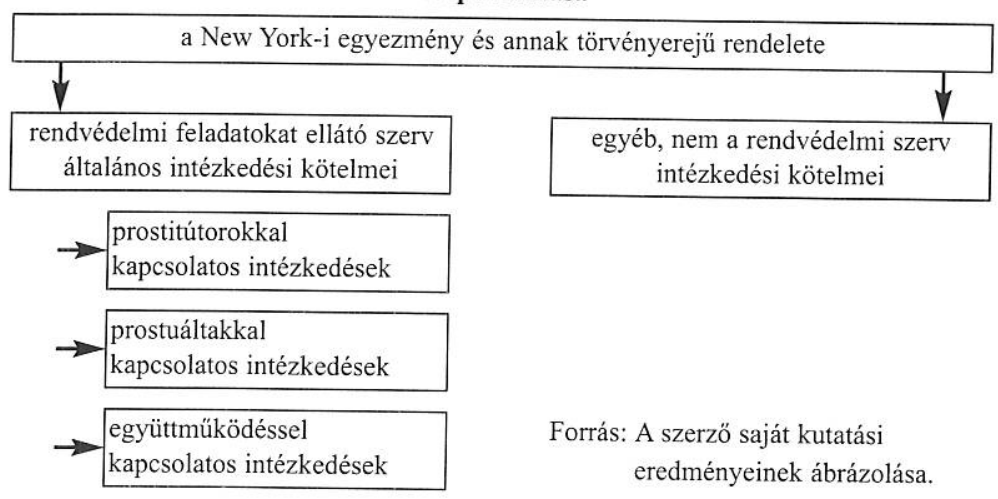

táson alapuló rendőri feladatok összességét jelentette. Az egyéb, nem rendvédelmi szerv intézkedési kötelmei föcsoport azokat az intézkedéseket foglalta magában, amelyek nem a jogalkalmazó, hanem a jogalkotó szerv jogharmonizációs feladatait határozták meg. Az első föcsoportba tizenegy, a második föcsoportba tizenhét cikkely került. A vizsgálat szempontjából relevanciát az első föcsoport alkot: a prostitútorokkal kapcsolatos intézkedések három (1., 2. és 20.), a prostituáltakkal kapcsolatos intézkedések négy (6., 16., 17., 19.), az együttmüködéssel kapcsolatos intézkedések szintén négy (8., 14., 15., 18.) cikkelyt foglaltak magukban. Bár a második föcsoport a tizenhét cikkelyével (3., 4., 5., 7., 9., 10., 11., 12., 13., 21., 22., 23., 24., 25., 26., 27., 28.) szerepe nem elhanyagolható, de a vizsgálat szempontjából irreleváns. A következőkben a csoportosítást egy-egy példacikkely ismertetésével illusztrálom, ezeket szó szerint idézem a törvényerejü rendeletből. (Tekintettel arra, hogy a törvényerejü rendelet a nemzetközi egyezmény szó szerinti fordítása, így az angol nyelvü ismertetéstől eltekintettem.) ${ }^{9}$

$9 \mathrm{Az}$ emberkereskedés és mások prostitúciója kihasználásának elnyomása tárgyában, New Yorkban, 1950. évi március hó 21. napján kelt nemzetközi egyezmény kihirdetéséröl szóló 1955. évi 34. törvényerejü rendelet. Hatályba lépett: 1955 . december 24.

http://net.jogtar.hu/jr/gen/hjegy_doc.cgi?docid=95500034.TVR\#lbj0idff7d 
1. $c i k k$

A jelen Egyezményben részes Felek kötelezik magukat arra, hogy mindazokat megbüntetik, akik más személy kéjelgésének kielégitésére:

1. prostitúció céljából megkeritenek, rábirnak, vagy elcsábitanak más személyt, akár annak beleegyezésével is,

2. más személy prostitúcióját kizsákmányolják, akár annak beleegyezésével is.

Prostituáltakkal kapcsolatos rendöri intézkedés

16. cikk

A jelen Egyezményben részes Felek egyetértenek abban, hogy szociális, gazdasági, nevelési, egészségügyi, valamint az ezekkel összefüggö területeken müködö szerveiken keresztül, álljanak bár közületi, avagy magánirányitás alatt, a prostitúció megelözésére, valamint a prostitúció és a jelen Egyezményben emlitett büncselekmények áldozatainak újranevelésére és a normális életviszonyokba való beillesztésére alkalmas intézkedéseket tesznek vagy elösegitik az ilyen intézkedéseket.

Együttmüködéssel kapcsolatos rendőri intézkedés

14. cikk

A jelen Egyezményben részes mindegyik Fél köteles a jelen Egyezményben emlitet büncselekményekre vonatkozó nyomozás eredményeinek központositásával és összehangolásával foglalkozó szervet létrehozni vagy fenntartani.

Ezeknek a szerveknek összesiteniök kell a jelen Egyezményben emlitett büncselekmények megelözése és elnyomása szempontjából hasznos értesüléseket és ugyanakkor más államok megfelelö szerveivel szoros kapcsolatot kell fenntartaniok.

Egyéb - nem rendvédelmi szerv - intézkedése

11. cikk

A jelen Egyezmény egyetlen rendelkezését sem lehet úgy értelmezni, mintha az Egyezményben részes valamely Félnek az általános büntető joghatóságra, mint nemzetközi jogi kérdésre vonatkozó álláspontját meghatározná.

Belügyi Szemle, 2017/10. 
A csoportosítás után a következőkben a hatályos ORFK-utasítás részletes vizsgálatával, az egyes és kettes pontokban rögzített feladataival foglalkozom.

\section{A prostitúcióval összefüggö rendészeti feladatok}

Az utasítás 1. pontjában rögzített feladatok közül megvizsgáltam, hogy a rendvédelmi szerv általános intézkedési kötelmei föcsoporton belül a prostitútorokkal, a prostituáltakkal és az együttmüködéssel kapcsolatos intézkedések megvalósulnak-e. A csoportosított nemzetközi egyezménnyel összefüggő feladatok foganatosítására e fejezeten belül egyik intézkedéssel összefüggésben sem került sor. A prostitútorokkal kapcsolatos intézkedések három (1., 2. és 20.), a prostituáltakkal kapcsolatos intézkedések négy (6., 16., 17., 19.), az együttmüködéssel kapcsolatos intézkedések szintén négy (8., 14., 15., 18.) cikkelyt foglaltak magukban, ezek végrehajtása az utasítás e fejezetében nem érvényesül.

2. számú ábra

Az utasítás 1. pontjával összefüggésben elvárt jogharmonizációs feladatok



Forrás: A szerző saját kutatási eredményeinek ábrázolása.

A 2. számú ábrán is jól látható, hogy bármelyik alcsoportot vesszük is alapul, a rendőri intézkedések feladat-meghatározásai a vonallal jelzett és a nemzetközi egyezmény által kijelölt kötelmeket nem érik el. A tanulmány második részében sor került a szabálysértési, valamint a szervezett bünözés elleni törvény részletes vizsgálatára. Összességében a magyar jogalkotó úgy értékelte, hogy a prostituáltak magatartása olyan jogellenes tevékenység, vagy mulasztás, amely veszélyes a társadalomra, ám az alaptörvény szerinti állami, társadalmi vagy gazdasági rendet, a természetes és jogi személyek, valamint a jogi személyiség nélküli szervezetek személyét vagy jogait a büncselekményként történő büntet- 
ni rendeléshez képest a szükségesnél kisebb fokban sérti és/vagy veszélyezteti, amelynek büntetendősége szükséges. A jogszabály ugyan csak keretrendelkezés, mert annak tartalmát más törvény és önkormányzati rendelet tölti ki. A szankció alkalmazását e tartalom megszegése vonja maga után. A tartalmi keretet egyrészt a szervezett bünözés, valamint az azzal összefüggő egyes jelenségek elleni fellépés szabályairól és az ehhez kapcsolódó törvénymódosításokról szóló 1999. évi LXXV. törvény, másrészt a szabálysértésekről, illetőleg a fövárosi, megyei és helyi illetékességü önkormányzatok testületi döntéseiről szóló 1999. évi LXIX. törvény (a továbbiakban: önkormányzati rendelet) adják. ${ }^{10}$ E jogszabályok tartalmazzák, hogy a prostituáltak milyen jogosultságokat gyakorolhatnak, és milyen kötelmeket kell megtartaniuk ahhoz, hogy ne váljanak törvénysértővé. Az üzletszerü kéjelgést a magyar joggyakorlat 1993ig büncselekményként, majd 1999 szeptemberéig pedig szabálysértésként kezelte. " Napjainkban a szabálysértési törvény a prostituáltak számára lehetövé teszi, hogy meghatározott szabályok betartásával e tevékenységet legálisan folytassák. A törvény a tevékenység legalitása mellett három objektív kitételt határoz meg, amelyhez az utasítás e pontja részleteiben igazodik.

A közrendvédelmi megfeleltetés szempontjából a rendőrhatóság csak a prostituáltak munkavégzésének ellenörzésére, az önkormányzatokkal való együttmüködésre, és a rendőrség saját hatáskörében megengedett szankcióinak kiszabására intézkedik. Aggályos intézkedési kötelmek ezek, hiszen a prostituáltak alkotmányos és emberi jogai, valamint önmagában a nemzetközi egyezmény cikkelyei sérülnek. Mivel a szabálysértési törvény a prostituáltakra - bizonyos szabályok meg nem tartása esetén - bünelkövetőként tekint, ezért a hatóság őket nyilvántartásba veszi. A hatósági nyilvántartás pedig különleges, speciális nyilvántartás, így sérül az egyezmény 6. cikkelye. Továbbá amikor a rendőr ,,igazoltat”, helyszíni bírságot szab ki, előállít, szabálysértési őrizetbe vételt foganatosít, azt nem személlyel, hanem személlyel mint rendszerben rögzített prostituálttal szemben alkalmazza. (Az „igazoltatás” során a rendőr priorál, és személyazonosságot állapít meg. A prioráláskor

10 A szervezett bünözés, valamint az azzal összefüggő egyes jelenségek elleni fellépés szabályairól és az ehhez kapcsolódó törvénymódosításokról szóló 1999. évi LXXV. törvény. Hatályba lépett: 1999. július 5. https://net.jogtar.hu/jr/gen/hjegy_doc.cgi?docid=99900075.TV ; a szabálysértésekröl szóló 1999. évi LXIX. törvény. Hatályba lépett: 1999. június 15. https://mkogy.jogtar.hu/?page=show\&docid=99900069.TV

11 A büntető jogszabályok módosításáról szóló 1993. évi XVII. törvény. Hatályba lépett: 1993. március 2. https://mkogy.jogtar.hu/?page=show\&docid=99300017.TV; a szabálysértésekröl szóló 1999. évi LXIX. törvény. Hatályba lépett: 1999. június 15. https://mkogy.jogtar.hu/?page=show\&docid=99900069.TV 
adatot nemcsak a bünügyi, hanem a szabályértési nyilvántartásból is igényel, azaz a nyomozó hatóság - túlmenöen a nyilvántartásba vételi tevékenységen - a 6. cikkelyben szereplö ellenőrzési tilalmat is megszegi.) A szabálysértési rendszer ismétlődő, ciklikus folyamatot feltételez, így aggályos a nemzetközi egyezmény 6 . cikkelye érvényesitésének garanciája. De ugyanígy sérti az utasítás az összesítő jelentés elkészítését is, amely szintén a prostituáltak nyilvántartásba vételén alapul, és azt az ORFK évente összesíti:

„, 5. A tiltott prostitúció megelözése, megszakitása és visszaszoritása érdekében szervezett fokozott ellenörzések során:

a) kiemelt figyelmet kell forditani a védett övezetekre és az Szbtv. 7. § (3) bekezdésében meghatározott helyekre;

b) rendszeresen és visszatéröen kell ellenörizni a védett övezeteket, továbbá az Szbtv. 4. §a) pontja alapján üzletnek minösülö olyan helyiségeket, amelyek a tiltott prostitúcióval, valamint a hozzá kapcsolódó egyéb jogsértésekkel összefüggésbe hozhatók..."

„9. A megyei rendörfókapitány-helyettesnek (rendészeti), a Budapesti Rendör-fökapitányság rendészeti rendörfókapitány-helyettesének, a Repülötéri Rendör Igazgatóság (a továbbiakban: RRI) rendészeti igazgatóhelyettesének és a Készenléti Rendörség (a továbbiakban: KR) rendészeti igazgatójának a prostitúcióval összefüggö jogsértések kezelése érdekében tett intézkedéseikröl értékelö jelentést kell késziteniük, amelyet minden év február 1. napjáig az ORFK rendészeti föigazgatójának terjesztenek fel."

A közegészségügyi és gazdasági megfeleltetés szempontjából az utasitás szintén a két nagy törvényhez igazodik. Azzal, hogy az Alkotmánybíróság az orvosi igazolás azon részét, amely az emberi és alkotmányos alapjogok gyakorlása tekintetében visszásságot tartalmazott megsemmisítette, az egyezmény 6 . cikkelyében foglaltakat részben teljesítette. Az egyezmény kimondja ugyanis, hogy a szerződésben részes felek kötelesek minden olyan intézkedést megtenni, és minden olyan normát hatályon kívül helyezni, eltörölni, amely a prostitúcióval foglalkozó vagy azzal gyanúsított személy különleges nyilvántartásba vételét, igazolványkényszerét, ellenőrzési/bejelentési kötelmét előírja. A korábbi törvény az orvosi igazolást olyan pejoratív módon rendelte kezelni, amely személyiségi és emberi jogokat sértett. A prostituáltak részére kiadandó orvosi igazolásról szóló 41/1999. (IX. 8.) EüM rendelet a prostituált személyére és foglalkozására irányuló közvetlen rendelkezést tartalmazott. ${ }^{12}$ Tekintettel arra,

12 A prostituáltak részére kiadandó orvosi igazolásról szóló 41/1999. (IX. 8.) EüM rendelet. Hatályba lépett: 1999. június 15 . http://mkogy.jogtar.hu/?page=show\&docid=99900069.TV 
hogy az a nemzetközi joggal összhangban nem állt, ezért azt az Alkotmánybíróság az 1/2011. (I. 14.) számú $\mathrm{AB}$ határozatával 2011. január 14-én megsemmisítette. ${ }^{13} \mathrm{~A}$ hatályos szabályozás által előírt orvosi igazolás munkavégzésre és személyi érintettségre irányuló utalást és ezáltal regisztrált nyilvántartást nem tartalmaz. ${ }^{14} \mathrm{Ha}$ viszont a prostituáltnak nincs a munkavégzéshez szükséges orvosi igazolása, akkor a rendőrség büntetőbírság kiszabására és arányban álló, a szükségesség alapelvére tekintettel akár személyi szabadságot korlátozó intézkedés foganatositására is jogosulttá válik. Jogalapját a közegészségügyi védelemhez füződő társadalmi érdek teremti meg. A gazdasági szabályok betartása egyéni vállalkozói igazolvány meglétét, és rendszeres jövedelemadó megfizetését feltételezi. Tekintettel arra, hogy az egyéni vállalkozóról és az egyéni cégröl szóló törvény alapján a prostituáltak tevékenysége szolgáltatás jogcímén gyakorolható, valamint a személyi jövedelemadóról szóló törvény alapján adóköteles, így ennek megtartása a gazdasági kritériumnak való megfeleltetést garantálja. ${ }^{15} \mathrm{Ha}$ a prostituáltak e szabályokat nem tartják meg, akkor az állam oldalán gazdasági hiány, kár keletkezik. Mindezek ellenőrzésére, valamint hiány és/vagy normasértés esetén gazdasági szankció alkalmazására a Nemzeti Adó- és Vámhivatal jogosult. ${ }^{16}$ Az együttmüködés, ellenőrzés és a szankció alkalmazása az utasításban külön pontként szerepel:

„5. A tiltott prostitúció megelozzése, megszakitása és visszaszoritása érdekében szervezett fokozott ellenörzések során:

c) lehetöség szerint be kell vonni a fóvárosi és megyei kormányhivatalok népegészségügyi szakigazgatási szerveit, valamint az önkormányzatok, a Nemzeti Munkaügyi Hivatal Munkavédelmi és Munkaügyi Igazgatóság és a Nemzeti Adó- és Vámhivatal szerveit is."

„6. Amennyiben az Szbtv. 4. §-ának e) pontja szerinti prostituálttal szemben tevékenysége miatt rendöri intézkedésre kerül sor, minden esetben vizsgálni kell a fertőzö betegségek és a járványok megelözése érdekében szükséges járványügyi intézkedésekről szóló 18/1998. (VI. 3.) NM rendelet 5. számú

13 1/2011. (I. 14.) AB határozat. Hatályba lépett: 2011. január 14.

http://public.mkab.hu/dev/dontesek.nsf/0/912C0127947A099BC1257ADA005259DB?Open Document

14 Kovács István: A prostitúció jelensége és társadalmi kontrolljának vizsgálata empirikus módszerekkel. PhD-értekezés. Nemzeti Közszolgálati Egyetem, Budapest, 2016

15 A személyi jövedelemadóról szóló 1995. évi CXVII. törvény. Hatályba lépett: 1995. december 22. https://net.jogtar.hu/jr/gen/hjegy_doc.cgi?docid=99500117.TV; az egyéni vállalkozóról és az egyéni cégröl szóló 2009. évi CXV. törvény. Hatályba lépett: 2009. november 16.

https://net.jogtar.hu/jr/gen/hjegy_doc.cgi?docid=a0900115.tv

16 A Nemzeti Adó- és Vámhivatalról szóló 2010. évi CXXII. törvény. Hatályba lépett: 2010. november

19. http://net.jogtar.hu/jr/gen/getdoc2.cgi?docid=A1000122.TV

Belügyi Szemle, 2017/10. 
melléklete szerint kiállitott orvosi igazolás meglétét, amelynek helyszini hiánya esetén a rendör a Szabs. tv. 172. \$-a szerinti tiltott prostitúció miatt feljelentést tesz, vagy helyszini birságot szab ki."

A magyar jogalkotás a szabálysértés területén a nemzetközi egyezmény rendelkezéseit nem tartotta irányadónak. A törvény a prostituáltak részére az egészségügy, a közrendvédelem és a gazdaság területén is többletkötelmeket határoz meg, míg a nemzetközi joganyag rendelkezéseit figyelmen kívül hagyja. Ezt a hatályos ORFK-utasítás is követi. Minden olyan hiányosság és visszásság, amelyet a szabálysértési jog a prostituáltaknak megenged, azt a hatályos ORFK-norma is alkalmazza. Aggályos továbbá, hogy a meglevő hiányosságokon és visszásságokon túl - amelyek a nemzetközi egyezmény céljaival összeegyeztethetetlenek és ellentétesek - az utasítás 9. pontjában felvetettekről külön országos hatáskörü nyilvántartást is vezet, duplán megszegve az egyezmény 6. cikkelyében foglaltakat. Az utasítás e fejezetében olyan intézkedési kötelmet, amely a prostitútorok üldöztetésére, szankcionálására, a prostituáltak reszocializációjára, a társadalomba való beilleszkedésének elősegítésére, illetve külföldi hatósággal történő áldozatvédelmi együttműködésre irányulna, nem találtam. Részeredményként ezért megállapítom, hogy az utasítás e fejezetének 1. szakaszában rögzített rendelkezések a nemzetközi egyezmény szellemével éles ellentétben állnak, azok a prostituáltak alkotmányos és emberi jogait sértik/veszélyeztetik.

\section{A prostitúcióhoz kapcsolódó büncselekmények és az emberkereskedelem kezelésével kapcsolatos bünügyi, bünmegelôzési és áldozatsegítési feladatok}

Az utasítás 2. pontjában rögzített feladatok közül megvizsgáltam, hogy a rendvédelmi szerv általános intézkedési kötelmei föcsoporton belül a prostitútorokkal, a prostituáltakkal és az együttmüködéssel kapcsolatos intézkedések megvalósulnak-e. A csoportosított nemzetközi egyezményhez kapcsolódó feladatok foganatosítására e fejezeten belül az összes intézkedéssel összefüggésben sor került. A prostitútorokkal kapcsolatos intézkedések három (1., 2. és 20.), a prostituáltakkal kapcsolatos intézkedések négy (6., 16., 17., 19.), az együttmüködéssel kapcsolatos intézkedések szintén négy (8., 14., 15., 18.) cikkelyt foglaltak magukban, ezek végrehajtása az utasítás e fejezetében érvényesült. 
3. számú ábra

Az utasítás 2. pontjával összefüggésben elvárt jogharmonizációs feladatok

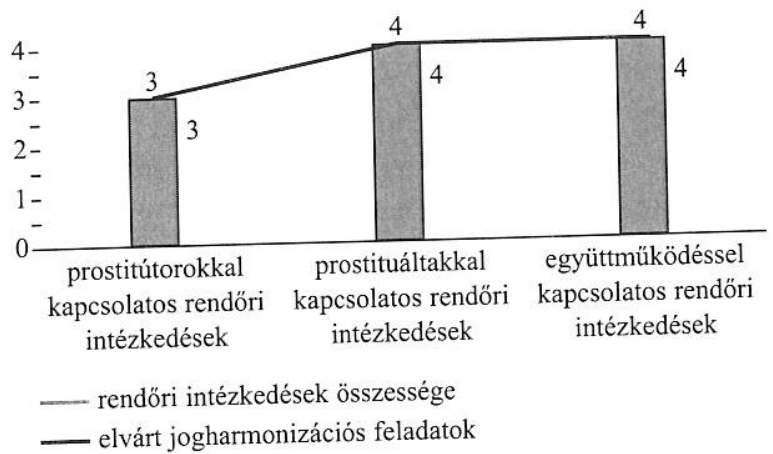

Forrás: A szerző saját kutatási eredményeinek ábrázolása.

A 3. számú ábra is jól szemlélteti, hogy bármelyik alcsoportot vesszük is alapul, a rendőri intézkedések feladat-meghatározásai maximálisan elérik a vonallal jelzett és a nemzetközi egyezmény által kijelölt kötelmeket. A tanulmány első részében sor került a hazai büntető törvénykönyv részletes vizsgálatára. Összességében a magyar jogalkotó úgy értékelte, hogy mások szexuális úton történő kizsákmányolása, és ezáltal mások emberi jogainak sérelme az egyik legmagasabb büntetési tétellel sújtott büncselekmény, amelyet büntetőnorma pönalizált. Magyarország a szexuális célú emberkereskedelem és a prostitúcióból hasznot húzó, kizsákmányoló, és élősdi cselekmények ellen szigorúan a jogszabályi keretek között, a nemzetközi joggal összhangban fel kíván lépni, amelyet a rendőrség utasítása is tükröz.

A prostitútorokkal kapcsolatos intézkedési kötelem az utasítás több pontjában is megjelenik. A rendőrség célul tüzte ki, hogy a nemzetközi joggal összhangban a szexuális célú emberkereskedelem, valamint a prostitúciós büncselekmények (kerítés, kitartottság, prostitúció elősegítése, gyermekprostitúció elősegítése stb.) elkövetőit elfogja, az ezzel kapcsolatos büncselekményeket felderíti. Az intézkedés nemcsak a klasszikus futtatói magatartásokat öleli fel, hanem a nemzetközi egyezménnyel összhangban a közvetítő jellegü magatartások (szexuális munkát közvetítő cégek) felderítése is megvalósul. Az utasítás e feladatok koordinálására és végrehajtására külön központosított szervezeti egységet hozott létre, amely a végzett tevékenységet folyamatosan elemzi, értékeli, majd a konklúziók alapján megteszi a szükséges fejlesztő intézkedéseket. 
„21. A KR NNI Korrupció és Gazdasági Bünözés Elleni Föosztálya gondoskodik a világháló folyamatos figyeléséröl abból a szempontból is, hogy az internet emberkereskedelem vagy prostitúcióra kényszerités céljából történö felhasználása felderithetővé váljék. Kiemelt figyelmet kell forditani az escort-, örökbefogadási vagy házasságközvetitö ügynökségek ilyen irányú megjelenésére, továbbá a gyermek- és fiatalkorú áldozatok és a velük történt visszaélések interneten keresztül történö azonositására."

A prostituáltakkal kapcsolatos intézkedési kötelem az utasítás több pontjában is megjelenik. A prostituáltakat - ha ők a felsorolt szexuális célú emberkereskedelem, vagy a prostitúciós bủncselekmények áldozatai - joggyakorlásukban segíti. Az utasítás magában foglalja az áldozatvédelmi, a reszocializációs és a társadalomba való reintegrálódást segítő intézkedések összességét. Az utasítás kiterjed a büncselekmény áldozatai jogainak gyakorlásának biztosítására, a reintegrálás és reszocializáció, valamint a civil szervezetekkel történő együttmüködésre külön rendelkezést tartalmaz. A rendörség az utasításban a nemzetközi joggal összhangban minden olyan intézkedést foganatosít, amelyet számára a nemzetközi egyezmény elöír, és az harmonizál az egyezmény preambulumában megjelölt célokkal.

„26. A nemzetközi emberi jogi egyezményekböl fakadó kötelezettségek teljesitése érdekében a rendöri szervek biztositják, hogy az áldozatok a jogszabályok alapján az öket megilletö jogokat gyakorolhassák. Gondoskodnak továbbá arról, hogy az áldozat megfelelö segitségben és védelemben részesüljön..."

Az együttmüködéssel kapcsolatos intézkedési kötelem az utasítás több pontjában is megjelenik. Az utasításban a rendőrség szexuális célú emberkereskedelemmel, valamint a prostitúciós büncselekményekkel érintett nemzetközi együttmüködési szerepvállalása érvényesül. A büncselekményekkel kapcsolatban a rendőrség naprakész nyilvántartást vezet, társhatósági feladatokat lát el, folyamatos elemzö-értékelő tevékenységet végez. A beszerzett információkat, valamint az éves összefoglalásokat a nemzetközi és az egyezményben részes államokkal megosztja, bünmegelőzési stratégiát dolgoz ki. Olyan preventív, és realizáló stratégiát alkalmaz, amely a nemzetközi jog által előirt kötelmeket százszázalékosan abszolválni tudja, ezáltal az emberi és alkotmányos jogok gyakorlását biztosítja.

„20. A KR Nemzeti Nyomozó Iroda a határon átnyúló, több országot érintö emberkereskedelem és prostitúcióra kényszerités elleni hatékony fellépés érdekében - a nemzetközi bünügyi együttmüködés szabályai alapján - szük- 
ség esetén kezdeményezi közös nyomozócsoportok létrehozását, kialakitja a nyilt és titkos együttmüködés egységes elvek mentén történö szabályozását."

A magyar jogalkotás a büntetőjog területén a nemzetközi egyezmény rendelkezéseit - az előkészület büntetendősége kivételével - megtartotta. A szexuális célú, kizsákmányoló, élősdi jellegü büncselekmények elkövetői a törvény egyik legszigorúbb büntetésével találhatják szembe magukat. Ezt a hatályos ORFK-utasítás követi. Minden olyan rendelkezés, amely a büncselekmény elkövetőinek üldöztetését elöírja, az áldozatok jogainak gyakorlását biztosítja, és a tagállamok közötti együttmüködés lehetőségét és kötelmét megteremti, az megtalálható az ORFK-utasítás 2. pontjában. Részeredményként megállapítottam, hogy az ORFK-utasítás 2. pontjában foglalt rendelkezések a nemzetközi joggal összhangban állnak. Apró, ám szembetünő hiányosság viszont, amelyet a módosító rendelkezés sem küszöbölt ki, hogy az utasítás I. fejezetében az általános rendelkezés csupán az emberkereskedelem vonatkozásában sorol fel konkrét büntető tényállást, a prostitúciós büncselekmények felsorolását viszont mellőzi. Ez ambivalens azzal, hogy egyébként az utasítás 2 . pontjában rögzített cím - helyesen - nemcsak az emberkereskedelemre, hanem a prostitúcióval kapcsolatos élősdi jellegü, kizsákmányoló büncselekményekre ugyanúgy vonatkozik. E tekintetben a jogszabály módosítására van szükség.

\section{Összegzés}

A jogrendszer nem azonos szintü normák koordinált rendszere, hanem különböző szintü jogi normák hierarchiája. Olyan általános és egyedi normák öszszessége, amelyek annak az elvnek a figyelembevételével kapcsolódnak egymáshoz, hogy maga a jog szabályozza saját maga megteremtését. Ebbe a rendszerbe nem csupán az általános, hanem az egyedi normák is illeszkednek, ellenétben azokkal az elképzelésekkel, amelyek a jogforrási hierarchiát csak a normatív aktusokra (vagy esetleg csak jogszabályokra) szükítik le. ${ }^{17}$ Éppen ezért is van nehéz helyzetben az ORFK-utasítás, hiszen két egymástól független, társadalmi életviszony szabályozását megteremtő törvény feladatmeghatározásainak kivitelezését köteles végrehajtani. A Magyarországon uralkodó félreglementációs és félabolicionista rendszereket megteremtő jogi szabályozás ambivalens végrehajtási intézkedéseket szül. A félreglementá-

17 Hans Kelsen: Pure Theory of Law. University of California Press, Los Angeles, 1967; Hans Kelsen: General Theory of Law and State. Harvard University, Cambridge, 1946

Belügyi Szemle, 2017/10. 
ciós és félabolicionista szemlélet a futtatói és - törvénysértés esetén - a prostitúciós tevékenységet is egyaránt büntetendő cselekményként kezeli, ami éles ellentétben áll az egyezménnyel. ${ }^{18} \mathrm{Az}$ utasításnak két felette álló jogszabály rendelkezéseit kell kiszolgálnia. Az előbbiekben taglaltaknak jellemző példája a „melyik ujjamat harapjam meg?” típusú kérdés.

A tanulmánynak pontosan az erre való rávilágítás volt a célja, hogy a nemzetközi egyezmény rendelkezéseit általános feladatként értelmezte, nem pedig jogágra lebontva csoportosította. Így kaphattuk csak meg azt a teljes képet, hogy az egyezményben foglalt kötelmek teljesítése és jogok gyakorlása nemcsak a büntető, hanem a szabálysértési szabályozásban is kell hogy szerepeljen. Megoldotta a helyi és/vagy megyei önkormányzat a védett zóna kijelölését Magyarországon? Szükséges és arányban áll-e a prostituált szabálysértési őrizetbe vétele, ha nincs orvosi igazolása? Szabálysértési eljárás esetén a rendőrség miért nem teszi meg az áldozatvédelmi intézkedéseket, miért nem érvényesül a megfelelő tájékoztatás, és a reszocializáció? Számtalan olyan kérdés van, amely a jogszabály ambivalens jellegéből adódik, miközben ezek megválaszolása már nemcsak a hazai, hanem a nemzetközi színtéren is megtörtént. 2003-ban a türelmi zónák kijelölésével kapcsolatos - önkormányzati - feladatok elmulasztására - így a rendőrség utasításban meghatározott feladataira az állampolgári jogok országgyülési biztosa általános helyettesének állásfoglalása is rávilágított, azonban intézkedés azóta sem történt ${ }^{19}$. A Fővárosi Bíróság kimondta, hogy a jelenlegi jogalkalmazás a kihirdetett nemzetközi egyezmény szellemével ellentétes sérelmekhez vezet, intézkedés szintén nem történt. ${ }^{20} \mathrm{~A}$ Legföbb Ügyészség is rávilágított arra a tényre, hogy annyi év gondolkodása, erőfeszítései, jogi kísérletezése ellenére, a prostitúció problémáinak megoldásában elörelépés nem történt. ${ }^{21}$ 2013-ban az ENSZ Nőjogi Bizott-

18 Kovács István: i. m.; Borai Ákos: Prostitúció. Print 2000 Nyomda Kft., Budapest, 2003

19 ,A türelmi zónák kijelölését elmulasztó önkormányzatok több szempontból is sértik a prostituáltak alkotmányos alapjogait. Csorbulnak a prostituáltak emberi jogai; amikor-az önkormányzatok mulasztása miatt - jogaikat csak korlátozottan érvényesithetik. Sértik az emberi méltóság tiszteletben tartásának alkotmányos alapelvét azzal; hogy szükségtelenül, aránytalanul, kiszámithatatlanul és önkényesen korlátozzák a prostituáltak személyiségi jogainak gyakorlását..." Az állampolgári jogok országgyülési biztosa általános helyettesének 4007/2003. számú OBH állásfoglalása. ; 10 éves lett az Egyesület. Hetérák, 2010/5., 1-12. o.

20 „A prostitúciót kisérö nem kivánatos jelenségek leküzdéséhez nem az az út vezet, mely a döntést halogatva hallgat a problémákról. A jelenlegi rendezetlen jogi helyzet a prostituáltak 1955. évi 34. számú törvényerejü rendelettel kihirdetett New Yorki Egyezmény szellemével ellentétes sérelmeihez vezet." A Fövárosi Bíróság 2.K.31.607/2002/14. számú ítélete.

21 „A Legföbb Ügyészség értékelése arra a helyzetre kivánja felhivni a figyelmet, hogy annyi év gondolkodása, erőfeszitései, jogi kisérletezése ellenére, nem jutottunk elöbbre a prostitúció problémáinak 
sága szintén elmarasztalta Magyarországot. ${ }^{22}$ Véleményem szerint a prostitúció jogi szabályozása olyan mérföldkőhöz érkezett, amelyet már nem célszerü a szőnyeg alá söpörni. Rengeteg munka, kodifikáció, de legfőképpen államhatalmi akarat szükséges ahhoz, hogy a jelenlegi egymással ellentétes szabályozást kiküszöböljük, és a nemzetközi normában meghatározott célokat teljesítsük. A hipotézisemben foglaltakat, miszerint a rendőrség utasítása öszszeegyeztethetetlen a New York-i egyezmény szellemével, annak rendelkezései sértik a nemzetközi norma preambulumában megfogalmazott célokat, az leginkább a szabálysértési törvényben megfogalmazottakhoz igazodik, sikerült részben alátámasztanom. Nem sikerült annak teljes bizonyítása, hiszen az utasítás 2. pontjában meghatározottak harmonizálnak a nemzetközi egyezménnyel. Jelenleg a rendőrség prostitúcióval kapcsolatos intézkedési kötelmei olyan normára épülnek, amely a felette álló jogi szabályozás éles ellentétéből, és egyrészt a New York-i egyezmény deharmonizációjából, másrészt pedig annak harmonizációjából született meg.

\section{Javaslatok}

Mindenekelőtt le kell szögezni, hogy egy demokratikus jogállam szabályok nélkül nem működhet. ${ }^{23}$ A szabályok megtartására, és a müködés szavatolására a különböző jogágak védelmet garantálnak. A társadalmi együttélés szabályait mindannyian kötelesek vagyunk betartani. Aki ezeket az alapvető magatartási normákat betartani képtelen, az ellen a jog, esetenként szigorú szankciót alkalmazva, fellép. Vitathatatlan tény, hogy olyan súlyos büncselekmények tekintetében, amely emberi és alkotmányos, azaz velünk született jogainkat sér-

megoldásában. Az önkormányzatok mulasztására is visszavezethetö, hogy az utcai prostitúció Budapesten a város egész területére kiterjedt, $s$ nem szünt meg a védett övezetekben sem. Az ügyészség megállapitotta azt is, hogy a rendőrség több esetben közlekedési vagy más szabálysértés miatt helyszini birsággal sújtotta azokat a prostituáltakat, akik védett övezetben ajánlották fel szexuális szolgáltatásukat. Ezt a gyakorlatot törvényességi szempontból kifogásoljuk. A Legföbb Ügyészség megállapitása szerint a múlt század 60-as éveiben is a prostituáltakat ellenörizték, figyelték és vonták felelösségre és ma ugyanazt teszik azzal a különbséggel, hogy ma a büntetést a rendörség helyett a biróság szabja ki és az elzárás maximális mértéke a kétszerese, a pénzbirság pedig többszöröse a több mint negyven évvel ezelöttinek." A Legfőbb Ügyészség TLÜ.2149/2004/2-1. állásfoglalása.

22 Committee on the Elimination of Discrimination against Women: Concluding observations on the combined seventh and eighth periodic reports of Hungary adopted by the Committee at its fiftyfourth session (11 February - 1 March 2013).

http://www2.ohchr.org/english/bodies/cedaw/docs/co/CEDAW.C.HUN.CO.7-8.pdf

23 Ian Budge: The newchallenge of directdemocracy. Polity Press, Cambridge, 1996 
ti és/vagy veszélyezteti, az ultima ratio elvén alapulva a büntetöjog beavatkozni köteles. A magyar szabályozás a nemzetközi joghoz e téren kellőképpen alkalmazkodott. (Érdemes megfontolni viszont, hogy bizonyos büncselekmények tekintetében akár az elökészület büntetendőségének bevezetése is indokolttá válhat. Például a prostitúció elősegítése büncselekmény kapcsán, az esetlegesen masszázsszalonnak, vagy éjszakai bárnak nevezett, a joghézagokat megteremtö, és a legalitás látszatát keltő helyek, és magatartások milyen szankcionálást vonhatnának maguk után, esetükben az előkészületnek mint stádiumnak létjogosultsága lenne-e.) A büntetőjog által szabályozott társadalmi viszonyok védelmét a továbbiakban is szükséges fenntartani.

Ami viszont a szabálysértési rendszerünket illeti, elgondolkodásra késztet, hogy e szabályozás a következőkben fenntartható-e. Hazai viszonylatban is ismerjük azokat a fórumokat és döntéshozó szerveket, amelyek a kialakult helyzet fennállása miatt aggodalmaikat fejezték ki, 2013-ban ez pedig nemzetközi színtéren tetőzött. Mint ahogy azt korábban kifejtettem, nem a jelenség szabályozatlansága és öntörvényüségének jellege mellett kívánok érvelni, hanem olyan megoldást ajánlok, amely a prostituáltak populációját a társadalom pereméröl visszailleszti a társadalmi reintegrálódás folyamatába. Ahhoz, hogy akár a prevenciót, akár a nemzetközi normával kapcsolatos harmonizációt kellő időben, megfelelő helyen és módon tudjuk végrehajtani, szükségessé vált egy célirányos, megfelelő minőségủ és színvonalú, jól felépített - és az áldozati célcsoportokra irányuló - stratégia kidolgozása. ${ }^{24}$

A reglementációból adódó problémák, a hármas megfeleltetés, a prostituáltak oldalán megjelenö többletkötelmek elgondolkodtatnak, hogy vajon egy új szabályozás milyen mértékben és minőségben változtathatná meg a jelenség kezelését. Meglátásom szerint egy olyan új modell megteremtésére van szükség, amelynek alapját az emberi és alkotmányos jogok érvényesítése adhatná, amelyre az áldozatvédelem, a jogi szabályozás, a rendvédelmi munkavégzés, és a reszocializációs intézkedések sorozata mint alappillér épülne.

A rendőrségnek mint végrehajtó szervnek pedig empatikus, toleráns és legföképpen szakmailag kifogásolhatatlan, a hatályos szabályozásnak megfelelő intézkedéseket kell hoznia. Azok a populációk, amelyeket a társadalom kirekeszt, emberi, alkotmányos jogaiktól büncselekmények áldozataként megfosztottak, a rendvédelmi szervektől védelmet és együttmüködést várnak el, hogy biztonságban érezhessék magukat.

24 Kovács István: A magyar prostituált munkavállalók jogai és kötelezettségei Németországban, a jelenséggel kapcsolatos illegális migráció, valamint a poszt-traumatikus stressz szindróma kezelésének lehetőségei. Határrendészeti Tanulmányok, 2015/1., 77. o. 


\section{IRODALOM}

Borai Ákos: Prostitúció. Print 2000 Nyomda Kft., Budapest, 2003

Budge, Ian: The new challenge of direct democracy. Polity Press, Cambridge, 1996

Károli Gáspár: Szent Biblia. Magyar Bibliatársulat, Budapest, 2010

Kelsen, Hans: General Theory of Law and State. Harvard University, Cambridge, 1946

Kelsen, Hans: Pure Theory of Law. University of California Press, Los Angeles, 1967

Kovács István: A magyar prostituált munkavállalók jogai és kötelezettségei Németországban, a jelenséggel kapcsolatos illegális migráció, valamint a poszt-traumatikus stressz szindróma kezelésének lehetőségei. Határrendészeti Tanulmányok, 2015/1.

Kovács István: A prostitúció jelensége és társadalmi kontrolljának vizsgálata empirikus módszerekkel. PhD-értekezés. Nemzeti Közszolgálati Egyetem, Budapest, 2016

Kovács István: Jogharmonizáció vagy sem? Első rész: a New Yorki Egyezmény és a 2012. évi C. törvény - a Büntetö Törvénykönyv. Jogelméleti Szemle, 2017/2.

Pap Gábor: Az új jogalkotási törvényröl. Sectio Juridica et Politica, Tomus, 2011/1.

Torma András - Kalas Tibor - Nyitrai Péter - Czékmann Zsolt - Bodnár Norbert: Közigazgatási jog 1. Magyar Közigazgatási jog általános rész. Miskolci Egyetem Állam- és Jogtudományi Kar, Miskolc, 2012

\section{JOGSZABÁLYOK}

Az emberkereskedés és mások prostitúciója kihasználásának elnyomása tárgyában, New Yorkban, 1950. évi március hó 21. napján kelt nemzetközi egyezmény kihirdetéséről szóló 1955. évi 34. törvényerejü rendelet

A büntető jogszabályok módosításáról szóló 1993. évi XVII. törvény

A rendőrségröl szóló 1994. évi XXXIV. törvény

A személyi jövedelemadóról szóló 1995. évi CXVII. törvény

A prostituáltak részére kiadandó orvosi igazolásról szóló 41/1999. (IX. 8.) EüM rendelet

A szervezett bünözés, valamint az azzal összefüggő egyes jelenségek elleni fellépés szabályairól és az ehhez kapcsolódó törvénymódosításokról szóló 1999. évi LXXV. törvény

A szabálysértésekröl szóló 1999. évi LXIX. törvény

Az egyéni vállalkozóról és az egyéni cégről szóló 2009. évi CXV. törvény

A Nemzeti Adó- és Vámhivatalról szóló 2010. évi CXXII. törvény

A jogalkotásról szóló 2010. évi CXXX. törvény

1/2011. (I. 14.) AB határozat

A szabálysértésekről, a szabálysértési eljárásról és a szabálysértési nyilvántartásról szóló 2012. évi II. törvény

A büntető törvénykönyvről szóló 2012. évi C. törvény

A prostitúcióval összefüggő jogsértések és az emberkereskedelem kezelésével kapcsolatos rendőri feladatok végrehajtásáról szóló 13/2014. (V. 16.) ORFK utasítás 